\title{
インピーダンス計測のみに基づく圧電素子のパラメータ推定と 受動制振への応用*
}

\author{
高木 賢太郎*1, 大 嶋 和 彦*2, 稲 垣 大 雄*3
}

\author{
Parameter Estimation of Piezoelectric Elements Only Based on \\ Impedance Measurement and Its Application to Passive Damping
}

\author{
Kentaro TAKAGI*4, Kazuhiko OSHIMA and Daiyu INAGAKI \\ *4 Department of Mechanical Science and Engineering, Nagoya University, \\ Furo-cho, Chikusa-ku, Nagoya-shi, Aichi, 464-8603 Japan
}

\begin{abstract}
This paper discusses a parameter estimation method of piezoelectric elements aiming at piezoelectric shunt damping. The proposed method only requires electrical impedance measurements. The introduced impedance model, which consists of multiple vibration modes, indicates that the capacitance varies depending on the choice of the target mode. Two kinds of frequency-domain estimation methods, linear and nonlinear least squares methods, are proposed. The experimental results show the effectiveness of the proposed method and the validity of the estimated parameters.
\end{abstract}

Key Words : Piezo-Element, Parameter Estimation, System Identification, Smart Structure, Shunt Damping, Vibration Control

1.はじめに

構造物の制振手法として，外部電気回路（シャント 回路）を取り付けた圧電素子によって振動のエネル ギーを電気エネルギーに変換し消散することで制振を 行う, シャント制振と呼ばれる方法がある(1) (2).この 手法は，シャント回路に受動的な回路網を用いた場合 必ず安定になるうえ, 原理的には外部電源を必要とし ないため実用性も高い. しかしながら，たとえばイン ダクタと抵抗からなる LR 回路を用いた場合, 回路素 子值もしくは制振対象の不確かさや変動に対して制振 性能が敏感であることが知られている ${ }^{(3)}$. そのため, よい制振性能を得るためには，圧電素子を含めた構造 物の電気機械系の精密なパラメータ推定が必要である と考えられる.しかしながら，シャント制振における 従来の研究では, シャント回路の設計法や回路素子值 のチューニング法に関するものが多く(1) (2), パラメー タ推定に関する研究は少ない.

パラメータ推定に関する従来の研究として, Hagood と von Flotow は，圧電素子の端子間開放時と短絡時 の固有角振動数の差から, 電気機械結合係数を求める

* 原稿受付 2010 年 5 月 24 日.

*1 正員, 名古屋大学大学院工学研究科機械理工学専攻 (\$ 4648603 名古屋市千種区不老町).

*2 正員, 大同大学工学部総合機械工学科ロボティクス専攻 (业 457-8530 名古屋市南区滝春町 10-3).

*3 正員, (株)マキタ(画 446-8502 安城市住吉町 3-11-8).

E-mail : takagi@nuem.nagoya-u.ac.jp
方法を提案している(4). しかし多くの場合，固有角振 動数の変化はわずかであり, 計測誤差の影響を受けや すいと考えられる. そこで山田らは，インダクタを用 い共振を利用することで，電気機械結合係数をより精 度よく求める方法について提案している(5). Porfiri ら も同様にインダクタを用いた推定法を提案し，また圧 電材料の静電容量が振動モードごとに異なる可能性を 明らかにした ${ }^{(6)}$ 。一方 Kim らは，機械的な計測では なく,インピーダンス計測に基づく LR シャント回路 の調整則を導いた ${ }^{(7)}$. 電気的な計測だけであれば, 計 測用のセンサやアクチュエータが不要になるという特 長がある. しかしながら, 文献 ${ }^{(7)}$ では複数モードのモ デルを考慮しておらず，また電気機械結合係数などの 物理パラメータとインピーダンスの関係は陽に示され ていない. ほかに電気的な計測のみに基づくパラメー タ推定として, 高木らはセルフセンシング手法を応用 してパラメータ同定をする方法を提案しているが，ブ リッジ回路のバランスのため圧電素子の静電容量が既 知である必要がある ${ }^{(8)}$.

そこで本研究では, 電気インピーダンスの計測だけ で, 圧電素子の静電容量も含めて必要なパラメータ をすべて推定する方法を提案する. まず, 複数の振動 モードの存在を考慮し，圧電素子を含めた構造物の一 般的なモデルを示す. そして，圧電素子の電気的入出 


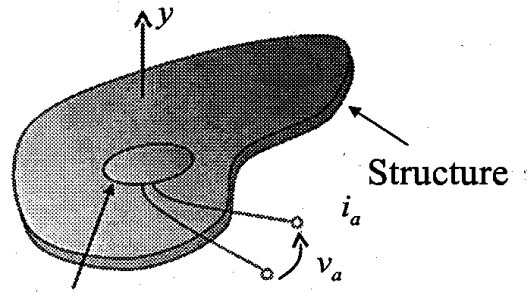

Piezoelectric material

Fig. 1 Schematic view of a structure embedded a piezoelectric material

力特性に着目し，インピーダンス伝達関数が圧電素子 と構造物のパラメータを含むことを示す.モデルから， 着目するモード以外のモードの影響により圧電素子の みかけの静電容量が周波数に依存して異なることを明 らかにし，モードキャパシタンスを定義する. 文献 ${ }^{(6)}$ の静的なモデルと比較すると, 本論文のモードキャパ シタンスはインピーダンスの動特性を考慮している. さらに, 計測したインピーダンスのデータから周波数 領域の同定手法によってパラメータを推定する方法を 提案する. 推定方法は, 線形最小 2 乗法と非線形最小 2 乗法のふたつを示す. 実験では, 圧電バイモルフ梁に 対して, まずインピーダンスの計測を行いパラメータ 推定を行う. 続いて, 直列 LR 回路を用いて圧電シャ ント制振実験を行い，提案手法によって推定されたパ ラメータの妥当性を制振結果から確認する.

\section{2. モ デル 化}

\section{$2 \cdot 1$ 一般的な圧電構造物のモデル 構造物の振} 動は連続体の運動であるため, 一般に偏微分方程式で モデル化され，無数の振動モードをもつ. 図 1 に圧電 素子を埋め込んだ構造物 (圧電構造物) の概念図を示 す. 本論文では, 線形振動を仮定し減衰が十分に小さ いとし, 圧電構造物の振動を次のようにモード展開さ れた形式で表現できると仮定する.

$$
y(t, \boldsymbol{r})=\sum_{i=1}^{\infty} \eta_{i}(t) \phi_{i}(\boldsymbol{r})
$$

ここで $t$ は時刻, $\boldsymbol{r}$ は位置変数, $y$ は構造物の振動変 位, $\eta_{i}(t)$ と $\phi_{i}(\boldsymbol{r})$ はそれぞれモード座標 (モード振幅) とモード形状関数である. なお, 有限要素法などで得

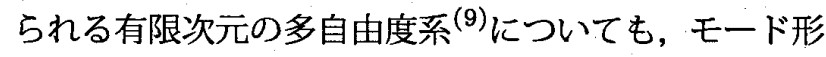
状関数をモードベクトルに置き換えることで, 以降の 議論は成り立つ. 本論文では圧電構造物のモデルを機 械系, 電気機械変換系, 電気系の 3 つのサブシステム からなると考え，それぞれの支配方程式を以下に示す。

機械系 (振動モ一ド方程式)

圧電特性を除いた構造物の運動方程式が振動モード
に展開されたとすると， $i$ 番目の振動モードは次の運 動方程式で表現できる.

$$
\begin{array}{r}
m_{i} \ddot{\eta}_{i}(t)+c_{i} \dot{\eta}_{i}(t)+k_{i} \eta_{i}(t)=-u_{i}(t)+\phi_{i}^{d} d(t) \\
(i=1,2, \ldots)
\end{array}
$$

ここで $u_{i}(t)$ は $i$ 次モードに寄与する逆圧電効果によ る力で, $d(t)$ は外力などの外乱である. $m_{i}, c_{i}, k_{i}$ は それぞれ，モード質量，モード減衰係数，モード剛性 である. $\phi_{i}^{d}$ は $d(t)$ の $i$ 次モードへの寄与を表す定数 である. また，モード減衰比 $\zeta_{i}$ および固有角振動数 $\omega_{i}$ は $m_{i}, c_{i}, k_{i}$ を用いて次式のように定義される.

$$
\zeta_{i}:=\frac{c_{i}}{2 \sqrt{m_{i} k_{i}}}, \omega_{i}:=\sqrt{\frac{k_{i}}{m_{i}}}
$$

\section{電気機械変換系 (圧電・逆圧電効果)}

圧電効果と逆圧電効果をモード空間で表現すると次 式で表される.

$$
\begin{aligned}
& u_{i}(t)=\psi_{i} v_{a}(t) \\
& i_{p}(t)=\sum_{i=1}^{\infty} \psi_{i} \dot{\eta}_{i}(t)
\end{aligned}
$$

ここで $v_{a}(t)$ は压電素子端子間に加わる電圧, $i_{p}(t)$ は圧 電効果によって発生する電流, そして $\psi_{i}$ は $i$ 次モードに おける電気機械変換の大きさを表す定数であり, モード 電気機械結合係数 (modal electromechanical coupling coefficient) と呼ぶ.

\section{電気系 (圧電素子の静電容量)}

圧電材料の電気的特性は図 2 に示すように, 圧電効 果を表す電流源とキャパシタでモデル化される.

$$
v_{a}(t)=\frac{1}{C^{S}} \int\left(i_{p}(t)+i_{a}(t)\right) d t
$$

ここで $i_{a}(t)$ は外部から圧電素子へ加えた電流, $C^{S}$ は 圧電素子の拘束静電容量 (blocked capacitance) であ る. 拘束静電容量とは, 機械系の変位が拘束されたと き,すなわち $\eta_{i} \equiv 0(i=1,2, \ldots)$ のときの静電容量と して定義される ${ }^{(4)}$. なお, 拘束静電容量は一定とし時 間とともに変化しないものとする.

\section{全体の系の支配方程式}

以上の式をまとめると, 系の支配方程式は以下のよ うに得られる.

$$
\begin{aligned}
M \ddot{\boldsymbol{\eta}}(t)+D \dot{\boldsymbol{\eta}}(t)+K \boldsymbol{\eta}(t)+\boldsymbol{\psi} v_{a}(t) & =\boldsymbol{\phi}^{d} d(t) \\
-\boldsymbol{\psi}^{\mathrm{T}} \boldsymbol{\eta}(t)+C^{S} v_{a}(t) & =q_{a}(t)
\end{aligned}
$$

ここで

$$
\begin{aligned}
& \boldsymbol{\eta}:=\left[\begin{array}{lll}
\eta_{1} & \eta_{2} & \cdots
\end{array}\right]^{\mathrm{T}} \\
& q_{a}:=\int i_{a} d t
\end{aligned}
$$




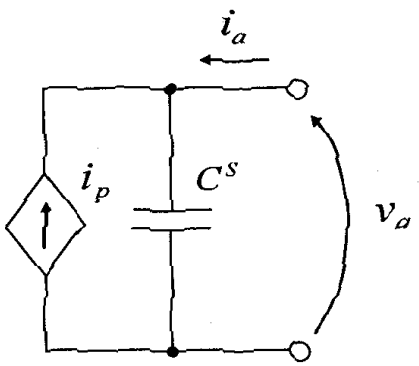

Fig. 2 Equivalent circuit of a piezoelectric material

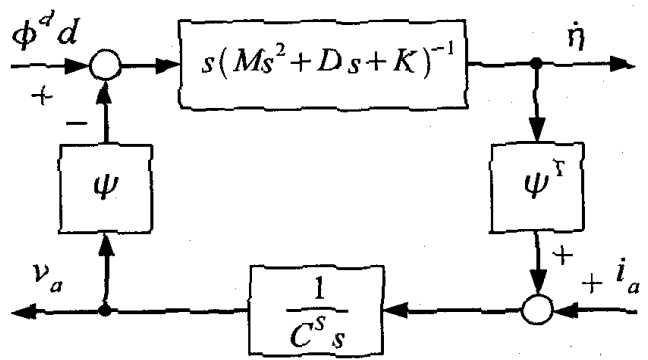

Fig. 3 Block diagram of the system

であり,また

$$
\left\{\begin{aligned}
M & :=\operatorname{diag}\left(m_{1}, m_{2}, \ldots\right), \\
D & :=\operatorname{diag}\left(c_{1}, c_{2}, \ldots\right), \\
K & :=\operatorname{diag}\left(k_{1}, k_{2}, \ldots\right), \\
\psi & :=\left[\psi_{1} \psi_{2} \cdots\right]^{\mathrm{T}}, \\
\phi^{d} & :=\left[\phi_{1}^{d} \phi_{2}^{d} \cdots\right]^{\mathrm{T}}
\end{aligned}\right.
$$

である，系のブロック線図を図 3 に示す，上のブロッ クが機械系であり，下のブロックが電気系である拘束 静霍容量を表す．機械系と電気係とは電気機械変換を 表す廿によって結合され，閍ループ系となることが わかる.

2.2 電気インピーダンスの多モードモデル＼cjkstart外 力 $d \equiv 0$ とし，シャント回路を接続せず，圧電素子の 電極端子から $v_{a}, i_{a}$ を計測する場合を考える。すなわ ち、インピーダンス(もしくはその逆であるアドミタ ンス)を計測する場合を考える.ここで， $i_{a}$ から $v_{a}$ ま での伝達関数であるインピーダンスを $Z_{v_{a} i_{a}}(s)$ と扔 く. $Z_{v_{a} i_{a}}(s)$ を求めるため, 式 (2)，(4)，(5) をラブラ 又变換し，それらを $i_{p}$ に関して解く. 得られた $i_{p}$ を 式 (6)に代大し整理すると次式を得る.

$$
Z_{v_{a} i_{a}}(s)=\frac{1}{s\left(C^{S}+\sum_{i=1}^{\infty} \frac{\psi_{i}^{2}}{s^{2}+2 \zeta_{i} \omega_{i} s+\omega_{i}^{2}}\right)}
$$

ここで $\bar{\psi}_{i}$ は，モード筫量により正規化されたモード 電気機械結合係数であり, 次式で定義する.

$$
\bar{\psi}_{i}:=-\frac{\psi_{i}}{\sqrt{m_{i}}}
$$

式 (12)から，压電素子のインピーダンスは戦純なキャ パシタではなく，圧電効果を表すパラメータ $\bar{\psi}_{i}$ と機 珹系のパラメータ $\zeta_{i}, \omega_{i}$ を含むことがわかる。 そのた め, インピーダンスを計測することによって電気系以 外のパラメータも推定できる. 文献 ${ }^{(7)}$ と比較すると, 式 (12) の伝達関数は物理パラメータを陽に含んだモ デルとなっている. 次に， $\bar{\psi}_{i}$ と従来提案されている一 般化電気機械結合係数との関係について述べるととも に，モードキャパシタンスを定義する。

\section{3 雷気機械結合係数とモードキャパシタンス} Hagood と von Flotowによって定義された一般化電気 機械結合係数 (generalized electromechanicai coupling coefficient) ${ }^{(4)}$ は，振動モードごとの圧電効果・逆圧電 効果の大きさを無次元量で表したもので, 端子間開放 時の固有振動数と端子間短絡時の固有振動数から求め ることができる. 複数の振動モードが存在するとき， 一一般化電笑機械結合係数は各振動モ一ドごとに存在し， $n$ 次モードの一般化電気機械結合係数を $K_{n}$ とおくと $K_{n}$ は次式で求められる.

$$
K_{n}^{2}=\frac{\left(\omega_{n}^{D}\right)^{2}-\omega_{n}^{2}}{\omega_{n}^{2}}
$$

ここで $\omega_{n}^{D}$ は端子間開放時の $n$ 次モード固有角振動 数， $\omega_{n}$ は端子間短絡時の $n$ 次モード固有角振動数で ある.な打，一般化電気機械結合係数の 2 乘 $K_{n}^{2}$ は, 端子間短絡から端子間開放したとき压電効果によって 生じるモード剛性の増加分と端子間短絡時のモード剛 性との比という物理的な解勫が可能である。これは, 端子間短絡と端子間開放とでモード質量が変化しない とすれば, 固有角振動数の 2 乗にモ一ド質坥をかけれ ばモード剛性になることから理解できる，

式 (14)の $\omega_{n}^{O}$ を求めるため, $i_{a}$ から $\dot{\eta}_{n}$ をでの伝達 関数を求め, その極を計算する。式 (12) と図 3 より。 $i_{a}$ から $\dot{\eta}_{n}$ までの伝達関数 $G_{\dot{\eta}_{n} i_{a}}$ は次式で与えられる。

$$
G_{\dot{\eta}_{n} i_{a}}(s)=\frac{-\psi_{n} s}{m_{n}\left(s^{2}+2 \zeta_{n} \omega_{n} s+\omega_{n}^{2}\right)} \cdot Z_{v_{a} i_{a}}(s)
$$

ここで， $\omega_{n}^{D}$ 认端子間開放時の無減衰国有㞕振動数で あるため，減袈比を 0とおくと，式 (15) の極の虚部は $\omega_{n}^{D}$ と一致する。 そのため, $\zeta_{i} \equiv 0(i=1,2, \ldots)$ とお き, 式 (15) O極を $\pm \mathrm{j} \omega_{n}^{D}$ (ここで $\left.\mathrm{j}:=\sqrt{-1}\right)$ と仮定す ると，分母が○であるための条件から次式が得られる。

$$
\left(\sim\left(\omega_{n}^{D}\right)^{2}+\omega_{n}^{2}\right)\left(C^{S}+\sum_{i=1}^{\infty} \frac{\bar{\psi}_{i}^{2}}{-\left(\omega_{n}^{D}\right)^{2}+\omega_{i}^{2}}\right)=0
$$

$i=n$ の場合仙注意して，式 $\{16)$ を整理すると

$$
\left(\omega_{n}^{D}\right)^{2}=\omega_{n}^{2}+\frac{\bar{\psi}_{n}^{2}}{C_{(n)}}
$$


となる.ここで $C_{(n)}$ は

$$
C_{(n)}:=C^{S}+\sum_{i=1, i \neq n}^{\infty} \frac{\bar{\psi}_{i}^{2}}{-\left(\omega_{n}^{D}\right)^{2}+\omega_{i}^{2}}
$$

として定義し, 本論文では式 $(18) の C_{(n)}$ を $n$ 次モー ドのモードキャパシタンス ( $n$-th modal capacitance) と呼ぶこととする. 式 (18) のモードキャパシタンス は, 式 (15) の伝達関数を用いて導出されたため周波 数特性が考慮されており，また $\omega_{n}^{D} \rightarrow 0$ とすると文献 (6)の静的なモードキャパシタンスと一致するため, 従 来からの自然な拡張になっていると考えられる. なお, 式 (17) から, 端子間を開放することにより固有角振 動数が $\omega_{n}$ から $\omega_{n}^{D}$ へと増加することがわかる. 以上 の議論から, $\bar{\psi}_{n}$ と $K_{n}$ の関係は, 式 (17) を式 (14)に 代入することにより次式で与えられる.

$$
K_{n}^{2}=\frac{\bar{\psi}_{n}^{2}}{C_{(n)} \omega_{n}^{2}}
$$

2.4 電気インピーダンスの単一モード近似モデル 式 (12) のインピーダンスは複雑であり, そのままで は推定に用いにくい，そこで, 着目する単一のモード だけでインピーダンス伝達関数の近似を行うことを考 える. 式 (12)の分母に打い, 着目する $n$ 次モード とそれ以外にわける.

$$
Z_{v_{a} i_{a}}(s)=\frac{1}{s\left(C^{S}+\frac{\bar{\psi}_{n}^{2}}{s^{2}+2 \zeta_{n} \omega_{n} s+\omega_{n}^{2}}+\Delta_{(n)}(s)\right)}
$$

ここで

$$
\Delta_{(n)}(s):=\sum_{i=1, i \neq n}^{\infty} \frac{\bar{\psi}_{i}^{2}}{s^{2}+2 \zeta_{i} \omega_{i} s+\omega_{i}^{2}}
$$

である. すなわち, $\Delta_{(n)}(s)$ を何らかの方法で近似す ることで, インピーダンス伝達関数を低次元化するこ とができる.

本論文では，式 (20) に示す $Z_{v_{a} i_{a}}$ を次式のように $\hat{Z}_{v_{a} i_{a}}$ として近似する.

$$
\hat{Z}_{v_{a} i_{a}}(s)=\frac{1}{s\left(C_{(n)}+\frac{\bar{\psi}_{n}^{2}}{s^{2}+2 \zeta_{n} \omega_{n} s+\omega_{n}^{2}}\right)}
$$

式 (20) から式 (22) の導出において, 次式のように $\Delta_{(n)}(s)$ を単に定数として近似した。

$$
C^{S}+\Delta_{(n)}(s) \approx C_{(n)}
$$

このように定数で近似する理由は, 式 $(21) の \Delta_{(n)}(s)$ には $n$ 次モードの伝達関数が含まれていないため である. そのため $n$ 次モードの前後の固有振動数 $\omega_{n-1}, \omega_{n+1}$ が $\omega_{n}$ から十分に離れている場合, $n$ 次
モード付近の固有振動数付近で $\Delta_{(n)}(s)$ は定数とみな せると考えられる. またその場合, 減衰比 $\zeta_{n-1}, \zeta_{n+1}$ が $\Delta_{(n)}(s)$ の周波数特性に与える影響はほとんどない と考えられる. さらに，式 (23) の左辺に $s=\mathrm{j} \omega_{n}^{D}$ を 代入して $\zeta_{i} \rightarrow 0(i=1,2, \ldots)$ とすると, 式 $(23)$ の右 辺に厳密に一致することが式 (18) よりわかる. まと めると, 着目する $n$ 次モードとそれ以外のモードの固 有值が十分離れており, かつ減衰比 $\zeta_{i}$ が十分小さい 場合, $n$ 次モード固有振動数付近の周波数において式 (23) はよい近似であると考えられる. 得られた式 (22) を見ると, モードキャパシタンス $C_{(n)}$, モード電気機 械結合係数 $\psi_{n}$, 固有角振動数 $\omega_{n}$, モ一ド減哀比 $\zeta_{n}$ の4つのパラメータがインピーダンスに含まれている ため, それらのパラメータを後述のようにインピーダ ンス計測から推定できる.

な扔, 式 (23) の近似が成立する場合, $n$ 次モード付 近の周波数における静電容量について以下の知見が得 られる. 式 $(22)$ より, $\omega \ll \omega_{n}$ のとき,

$$
\left|\frac{1}{\mathrm{j} \omega \hat{Z}_{v_{a} i_{a}}(\mathrm{j} \omega)}\right| \approx C_{(n)}+\frac{\bar{\psi}_{n}^{2}}{\omega_{n}^{2}}
$$

となり, $\omega \gg \omega_{n}$ のとき,

$$
\left|\frac{1}{\mathrm{j} \omega \hat{Z}_{v_{n} i_{n}}(\mathrm{j} \omega)}\right| \approx C_{(n)}
$$

となる. すなわち, $\omega<\omega_{n}$ ではみかけの静電容量が 大きくなる. さらに, $\omega>\omega_{n}$ であっても, みかけの静 電容量は拘束静電容量 $C^{S}$ とは異なることがわかる.

\section{3. インピーダンス伝達関数のパラメータ推定}

\section{1 線形最小 2 乗法 $\quad Z_{v_{a} i_{a}}$ の周波数応答が計} 測されたとして，そのパラメータ推定について考える. 本論文では周波数領域の最小 2 乗法によって推定を行 う方法を提案する. はじめに，推定值が一意に定まる 線形最小 2 乗法を示す.つぎに，推定の初期值が必要 であるが, より高い精度が期待できる非線形最小 2 乗 法を示す。

まず, 式 (22) で表されるインピーダンスの逆数に 着目し, 最小 2 乗法を適用することを考える. 式 (22) の逆数に着目する理由は, 分母のモードキャパシタ ンス $C_{(n)}$ はもともと $\Delta_{(n)}(s)$ を近似したものであり， $\Delta_{(n)}(s)$ の定数による近似誤差を最小化するためであ る. なお, 逆数ではなくインピーダンスを直接用いた パラメータ推定も可能であると予想されるが, 本論文 では検討しない. 式 (22) を有理式で表した分母多項 式, 分子多項式をそれぞれ $g_{\mathrm{den}}$ と $g_{\mathrm{num}}$ として定義し, 
次の線形最小 2 乗問題を考える.

$$
\begin{gathered}
\min \sum_{k=1}^{N_{s}}\left|\left(\frac{g_{\text {num }}\left(\mathrm{j} \omega_{\mathrm{s}}[k]\right)}{Z_{\mathrm{s}}[k]}-g_{\mathrm{den}}\left(\mathrm{j} \omega_{\mathrm{s}}[k]\right)\right) W_{l}\left(\mathrm{j} \omega_{\mathrm{s}}[k]\right)\right|^{2} \\
g_{\text {num }}(s):=s^{2}+2 \zeta_{n} \omega_{n} s+\omega_{n}^{2} \\
g_{\text {den }}(s):=C_{(n)} s\left(s^{2}+2 \zeta_{n} \omega_{n} s+\omega_{n}^{2}+\frac{\bar{\psi}_{n}^{2}}{C_{(n)}}\right)
\end{gathered}
$$

ここで, $Z_{\mathrm{s}}[k]$ は計測された複素インピーダンス, $\omega_{\mathrm{s}}[k]$ は対応する角周波数であり， $k=1,2, \ldots, N_{\mathrm{s}}$ はサンプ ル番号を表す. 評価関数に扣いて誤差が微分特性をも つため,それを相殺するような重み関数を選ぶことで, 高周波数に扔いて誤差に重み付けしないことにする. そこで，重み関数 $W_{l}$ は

$$
W_{l}(s)=\frac{1}{s}
$$

とした．なお，仮に $\bar{\psi}_{n} \rightarrow 0$ とした場合を考えると， $g_{\text {num }}=1, g_{\text {den }}=s C_{(n)}$ であり, ちょうど $g_{\text {den }}$ 中の $s$ と重み関数が相殺し評価関数中の誤差への周波数重み 付けがなくなることがわかる.

式 (24) は, ベクトル $\theta_{\mathrm{ls}} \in \mathbb{R}^{5}$

$\boldsymbol{\theta}_{\mathrm{ls}}:=\left[C_{(n)}, 2 \zeta_{n} \omega_{n} C_{(n)},\left(\omega_{n}^{2} C_{(n)}+\bar{\psi}_{n}^{2}\right), 2 \zeta_{n} \omega_{n}, \omega_{n}^{2}\right]^{\mathrm{T}}$

を用いて未知係数についてまとめると, 次式のように 行列を用いて表すことができる.

$$
\min _{\theta_{\mathrm{ls}}}\left\|A \boldsymbol{\theta}_{\mathrm{ls}}-\boldsymbol{b}\right\|^{2}
$$

ここで, 行列 $A \in \mathbb{C}^{N_{\mathrm{s}} \times 5}$, ベクトル $b \in \mathbb{C}^{N_{\mathrm{s}}}$ の $k$ 行 目をそれぞれ $A_{k}, b_{k}$ とおくと, $A_{k}, b_{k}$ は次式で表さ れる.

$$
\begin{aligned}
A_{k} & =\left[-\omega_{\mathrm{s}}[k]^{2}, \mathrm{j} \omega_{\mathrm{s}}[k], 1, \frac{-1}{Z_{\mathrm{s}}[k]}, \frac{-1}{\mathrm{j} \omega_{\mathrm{s}}[k] Z_{\mathrm{s}}[k]}\right] \\
b_{k} & =\frac{\mathrm{j} \omega_{\mathrm{s}}[k]}{Z_{\mathrm{s}}[k]}
\end{aligned}
$$

式 (29) の線形最小 2 垂法の解は次式で与えられる.

$$
\boldsymbol{\theta}_{\mathrm{lsopt}}=\left(A^{*} A+\overline{A^{*} A}\right)^{-1}\left(A^{*} b+\overline{A^{*} b}\right)
$$

ここで $A^{*}$ は $A$ の共役転置, $\bar{z}$ は $z$ 共役複素数を表 す.なお， $A^{*} A$ の固有值の比 (行列の条件数) が大き く, 逆行列を計算する際の数值誤差が問題となる場合 が多い，そこで，適当な実対角行列 $S$ を用いて，

$$
\theta_{\mathrm{ls}}=S \theta_{\mathrm{sls}}
$$

とスケーリングを行い, 式 (29) を $\theta_{\mathrm{sls}}$ について最小 化する.すると, 解は式 (32) の代わりに

$$
\theta_{\text {lsopt }}=S\left(S^{\mathrm{T}}\left(A^{*} A+\overline{A^{*} A}\right) S\right)^{-1} S^{\mathrm{T}}\left(A^{*} b+\overline{A^{*} b}\right)
$$

となる.これはちょうど式 (32) 中で $A \rightarrow A S$ と置 き換えたことに対応している。 $\boldsymbol{\theta}_{\text {lsopt }}$ の各要素を $\theta_{i}$ $(i=1,2, \ldots, 5)$ とおけば, 物理パラメータと一般化電 気機械結合係数の推定值は次のように求められる.

$$
\left\{\begin{aligned}
C_{(n)} & =\theta_{1} \\
\left|\bar{\psi}_{n}\right| & =\sqrt{\theta_{3}-\theta_{1} \theta_{5}} \\
\omega_{n} & =\sqrt{\theta_{5}} \\
\zeta_{n} & =\frac{\theta_{2} / \theta_{1}+\theta_{4}}{4 \sqrt{\theta_{5}}} \\
K_{n}^{2} & =\frac{\theta_{3}-\theta_{1} \theta_{5}}{\theta_{1} \theta_{5}}
\end{aligned}\right.
$$

$3 \cdot 2$ 非線形最小 2 乗法 本節では, 式 (22) で表 されるインピーダンスの逆数に直接, 非線形最小 2 乗 法を適用することを考える.

$$
\min _{\theta_{\mathrm{nls}}} \sum_{k=1}^{N_{\mathrm{s}}}\left|\left(\frac{1}{Z_{\mathrm{s}}[k]}-\frac{1}{\hat{Z}_{v_{a} i_{a}}\left(\mathrm{j} \omega_{\mathrm{s}}[k] ; \boldsymbol{\theta}_{\mathrm{nls}}\right)}\right) W\left(\mathrm{j} \omega_{\mathrm{s}}[k]\right)\right|^{2}
$$

ここで， $\hat{Z}_{v_{a} i_{a}}\left(\mathrm{j} \omega_{\mathrm{s}}[k] ; \theta_{\mathrm{nls}}\right)$ は式 $(22)$ である.また重み 関数は

$$
W(s)=\frac{W_{0}}{s}
$$

とする.ここで $W_{0}$ は定数であり, 圧電素子のキャパ シタンスの逆数と同程度のオーダーとなるよう選ぶの がよいと考えられる.これはキャパシタンスの值が通 常非常に小さく，数值誤差を避けるためである.また 重み関数を積分特性としたのは, インピーダンスの逆 数が微分特性を持つため, 微分特性を消して誤差への 周波数重みをなくすためである. なお， $\theta_{\mathrm{nls}}$ は次式で 表されるパラメータベクトルである.

$$
\boldsymbol{\theta}_{\mathrm{nls}}:=\left[\dot{C}_{(n)}, \psi_{n}, \omega_{n}, \zeta_{n}\right]^{\mathrm{T}}
$$

式 (36) は，次式のようにべクトル表記でき，適当 なソフトウェアを用いて最小值を数值的に探索するこ とができる.

$$
\min _{\theta_{\mathrm{nls}}}\left\|\boldsymbol{f}\left(\boldsymbol{\theta}_{\mathrm{nls}}\right)-\boldsymbol{b}_{\mathrm{nls}}\right\|^{2}
$$

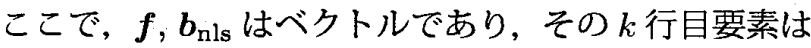
それぞれ $W\left(\mathrm{j} \omega_{\mathrm{s}}[k]\right) / \hat{Z}\left(\mathrm{j} \omega_{\mathrm{s}}[k] ; \theta_{\mathrm{nls}}\right), W\left(\mathrm{j} \omega_{\mathrm{s}}[k]\right) / Z_{\mathrm{s}}[k]$ である. 推定值の初期值には，前節の線形最小 2 乗法 で求めた值を用いることができる.なお，一般的に， 非線形最小 2 乗問題を数值最適化により解いた場合の 解の大域的最適性は保証されておらず，推定されるパ ラメータは初期值に依存することに注意されたい.

本節のまとめとして, パラメータを推定する手順を 以下に示す. 
Step 1. 着目するモードの固有振動数付近のいくつ かの周波数において, 複素インピーダンス $Z_{\mathrm{s}}=$ $\left|Z_{\mathrm{s}}\right| \exp \left(\mathrm{j} \angle Z_{\mathrm{s}}\right)$ (絶対值 $\left|Z_{\mathrm{s}}\right|$ と位相 $\left.\angle Z_{\mathrm{s}}\right)$ をイン ピーダンスアナライザや LCR メータなどを用い て計測する。

Step 2. 計測された複素インピーダンス $Z_{\mathrm{s}}$ をもと に，線形最小 2 乗法により式 (30)，(31)，(34), (35) を用いてパラメータを推定する. 結果が望 ましくない場合は Step 1.にもどり，対象とする モードの固有振動数付近での計測周波数を増やす.

Step 3. モデルとデータとの誤差を Step 2. の結果 よりもさらに小さくする場合, 式 (36) または (39) に示した非線形最小 2 乗法を用いて, 数值最適化 によりパラメータを推定する. 推定の初期值には Step 2.の值を用いることができる.

なお本手法は単一モード近似に基づくため，ある振動 モード一つについてパラメータ推定を行うものである が，互いに近接していない振動モードそれぞれについ て本手法を繰り返し適用することにより, 複数の振動 モードのパラメータを求めることができる.

\section{4. 実験}

4.1 実験装置実験に用いた圧電バイモルフ 梁は, 長さは $160 \mathrm{~mm}$, 幅 $20 \mathrm{~mm}$ であり, 自由長が $140 \mathrm{~mm}$ となるようにアルミの小片とバイスにて固定 した．圧電材 (富士セラミックス，C-201 材) は厚さ $0.5 \mathrm{~mm}$ であり，厚さ $0.1 \mathrm{~mm}$ のリン青銅の中心材両面 に接合されているため, バイモルフ梁としての厚さは $1.1 \mathrm{~mm}$ である. 実験では 1 次モードを対象に, まず インピーダンスを計測してパラメータ推定を行い, 続 いて得られたパラメータを用いて調整されたシャント 回路を用いて制振を行う.片側の圧電材をパラメータ 推定ならびに制振のために用い，もう一方の圧電材を 加振のための外乱用とした。

\section{2 パラメータ推定の実験}

4.2.1 方法 インピーダンスを計測するため, イ ンピーダンスアナライザ (HIOKI, 3522-50) を用いて 実験を行った. 図 4 に実験装置を示す. なお外乱用の圧 電材は短絡し影響を及ぼさないようにした，インピー ダンスアナライザの計測信号は定電圧モードで $0.5 \mathrm{~V}$ 振幅とし，64 回の平均をとった. 1 次モードの固有振 動数である $32 \mathrm{~Hz}$ 付近を含むように, $25 \mathrm{~Hz}$ から $40 \mathrm{~Hz}$ の間を 300 点計測した. 得られた複素インピーダンス に対して, 線形最小 2 乗法と非線形最小 2 乗法を適 用しパラメータを推定する. なお比較のため, 後述の 制振実験の方法によって加振をしたとき，周波数応答

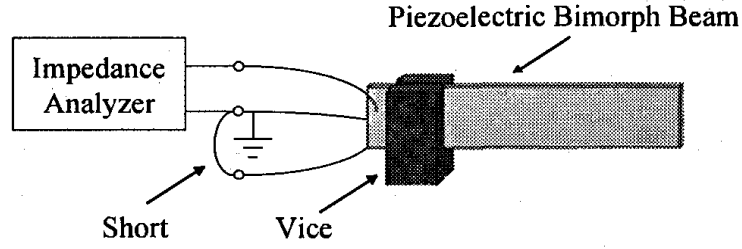

Fig. 4 Experimental setup for parameter estimation
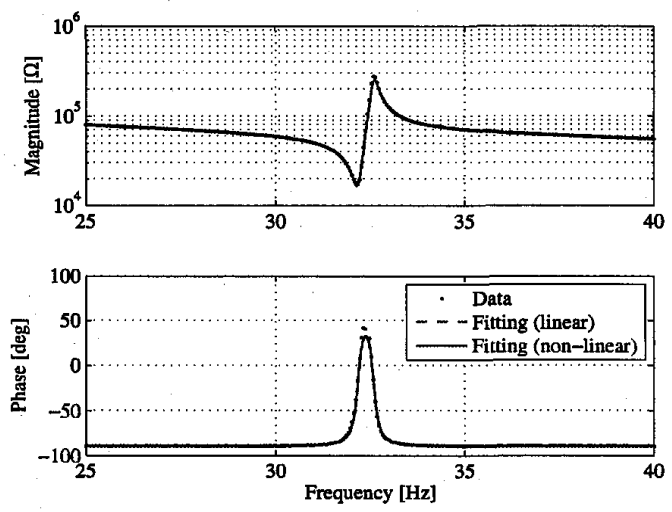

Fig. 5 Frequency response of the electrical impedance

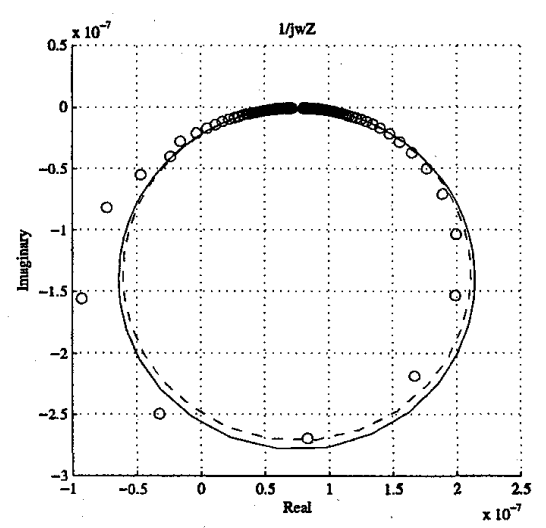

Fig. 6 Vector locus of the weighted admittance

のピークが最大となる周波数から $\omega_{1}^{D}, \omega_{1}$ を求め, 式 (14) より一般化電気機械結合係数を計算した.

4.2.2 結果と議論 図 5 に計測で得られた周波 数応答のボード線図を示す.・が計測值, 破線と実線 はそれぞれ線形最小 2 乗法と非線形最小 2 乗法によっ て推定されたパラメータを式 (22) に代入したモデル である．実線と破線はほぼ一致しており，推定された モデルは実測データによく一致していることがわか る. 推定において, 線形最小 2 乗法のスケーリングは $S=\operatorname{diag}\left(10^{-7}, 10^{-7}, 10^{-3}, 1,10^{4}\right)$ とし，非線形最小 2 乗法の重み定数は $W_{0}=10^{7}$ とした。これは，キャ パシタンスを扔よそ $10^{-7}$, 減衰比を扔よそ $10^{-2}$, 固 
Table 1 Estimated parameters based on the impedance measurement

\begin{tabular}{lccc}
\hline \hline Modal Parameters & Observing FFT & Linear Fitting & Nonlinear Fitting \\
\hline Capacitance $C_{(1)}[\mathrm{F}]$ & $\mathrm{N} / \mathrm{A}$ & $7.49 \times 10^{-8}$ & $7.46 \times 10^{-8}$ \\
Electromechanical Coupling Coefficient $\left|\bar{\psi}_{1}\right|\left[\mathrm{N} / \mathrm{V} \mathrm{kg}^{\frac{1}{2}}\right]$ & $\mathrm{N} / \mathrm{A}$ & $8.89 \times 10^{-3}$ & $8.83 \times 10^{-3}$ \\
Natural Frequency $\omega_{1}[\mathrm{rad} / \mathrm{s}]$ & $2.03 \times 10^{2}$ & $2.02 \times 10^{2}$ & $2.02 \times 10^{2}$ \\
Damping Ratio $\zeta_{1}[-]$ & $2.9 \times 10^{-3}$ & $3.56 \times 10^{-3}$ & $3.43 \times 10^{-3}$ \\
Generalized Electromechanical Coupling Coefficient $K_{1}^{2}[-]$ & 0.0273 & 0.0258 & 0.0256 \\
\hline \hline
\end{tabular}

有角振動数をおよそ $10^{2}$ とあらかじめ見積もったため である. 非線形最小 2 乗法は MATLAB Optimization Toolbox の Isqnonlin 関数を用い, 初期值には線形 最小 2 乗法によって推定された值を用いた. なお，非 線形最小 2 乗法の計算時間は約 0.096 [s] (Pentium M $1.2 \mathrm{GHz}, \mathrm{MATLAB}$ R2007) であり, 線形最小 2 乗法 の計算時間と比較すると約 4.6 倍であった.

表 1 に，3通りの方法で推定されたパラメータを示 す. 表において, 線形最小 2 乗法, 非線形最小 2 埀法 によって求めたパラメータをそれぞれ Linear Fitting, Nonlinear Fitting として示してある. また比較のため, 加振した時の振動を計測し Hagood と von Flotow の 方法で求めた $K_{1}^{2}$ を Observing FFT として示してあ る. 提案手法は, 線形, 非線形いずれの方法において も, すべてのパラメータについてほぼ同じ值が得られ た. 表 1 から, 線形と非線形とを比較すると, 減哀比 のみ約 $3 \%$, 他は全て $1 \%$ 末満のわずかなパラメータ0 違いがみられるが, 図 5 に示したように, インピーダ ンスで比較すると違いはほとんど無いと考えられる. さらに, ベクトル軌跡を用いて比較したものを図 6 に 示す. 図は複素平面上に $1 /(\mathrm{j} \omega Z(\mathrm{j} \omega))$ をプロットした ものであり，。が計測值，破線と実線はそれぞれ線形 最小 2 乗法と非線形最小 2 乗法によって推定された パラメータを式 (22) に代大し計算したモデルである. その差はわずかであるが, 非線形最小 2 乗法によるモ デルのほうが計測值との誤差が小さいように見えるた め, 非線形最小 2 乗法により推定された值を後述の制 振実験では用いることにする，なお，Hagood と von Flotow による方法によって得られた $K_{1}^{2}$ は，どちらの 提案手法とも約 $6 \%$ 異なっているが, それは $\omega_{1}^{D}-\omega_{1}$ に対して FFT(Fast Fourier Transform)の周波数間隔 の比が約 $15 \%$ あ，標本化誤差の影響を受けたためで あると考えられる. そのため䛊差を考慮すれば，一般 化電気機械結合係数について提案手法と従来の方法の 值はほぼ一致していると考えられる.

以上の推定実験の結果から, 提案したインピーダン スのモデルは実験データによく一致し，また提案した 推定手法によりパラメータを精度よく推定できること がわかる. なお，この実験対象では，線形最小 2 乗法 と非線形最小 2 乗法による推定結果の違いはほとんど
無く，どちらを使ってもよいと考えられる.

\section{3 制振実験}

4.3.1 方法 推定によって得られたパラメータ を用いて設計した直列 LR シャント回路の制振効果を 検証するために，圧電素子の端子間を短絡した場合， 開放した場合, そしてシャント回路を接続した場合の 3 通りについて加振実験を行う. 図 7 に実験装置を示す. パラメータ推定を行った圧電材にシャント回路を接続 し，また外乱用の圧電材にはアンプとファンクション ジェネレータを接続する。なお，インダクタンスの值 が非常に大きくなるため, 実験ではコイルによるイン ダクタの代わりとして OP アンプによる電子インダク タ (2)を作製して用いた。

直列 LR シャント回路の場合, 圧電素子端子間に加 わる電圧は次式で表わされる.

$$
L \frac{d i_{a}}{d t}(t)+R i_{a}(t)=-v_{a}(t)
$$

シャント回路素子を最適設計する方法として, 動吸振 器による類推に基づいて, 定点理論による設計法が提 案されている(1) (4). 定点理論を用いると，外力から 変位 (モード座標) までのピークゲインを最小にする 意味で最適な設計を行うことができる，定点理論によ り最適設計された素子值は次式で与えられる ${ }^{(8)}$.

$$
\begin{gathered}
L_{\mathrm{opt}}=\frac{1}{\omega_{n}^{2} C_{(n)}+\bar{\psi}_{n}^{2}} \\
R_{\mathrm{opt}}=\frac{1}{2\left(\omega_{n}^{2} C_{(n)}+\bar{\psi}_{n}^{2}\right)}\left(\sqrt{\frac{3 \bar{\psi}_{n}^{2}}{C_{(n)}\left(2-\sqrt{\frac{2 \bar{\psi}_{n}^{2}}{\omega_{n}^{2} C_{(n)}+\bar{\psi}_{n}^{2}}}\right)}}\right. \\
\left.+\sqrt{\frac{3 \bar{\psi}_{n}^{2}}{C_{(n)}\left(2+\sqrt{\frac{2 \bar{\psi}_{n}^{2}}{\omega_{n}^{2} C_{(n)}+\bar{\psi}_{n}^{2}}}\right)}}\right)
\end{gathered}
$$

なお, 式 (41), (42) で用いるキャパシタンスの值は モードキャパシタンス $C_{(n)}$ となっていることに注意 されたい. 表 1 に示した Nonlinear Fitting の值を用 いて設計されたインダクタンスと抵抗の值を表 2 に示 す。なお，線形最小 2 乗法によって推定した值から計 算した最適素子值は $3.20 \times 10^{2} \mathrm{H}$ と $1.27 \times 10^{4} \Omega$ であ り，それぞれ表 2 の值と比較して $0.6 \% ， 0.05 \%$ 程度 の非常に小さな違いしかなかった. そのため, 表 20 
Table 2 Optimal parameters of the shunt circuit

\begin{tabular}{cc}
\hline$L_{\text {opt }}$ & $R_{\text {opt }}$ \\
\hline $3.19 \times 10^{2} \mathrm{H}$ & $1.27 \times 10^{4} \Omega$ \\
\hline \hline
\end{tabular}

Shunt Circuit with a Synthetic Inductor

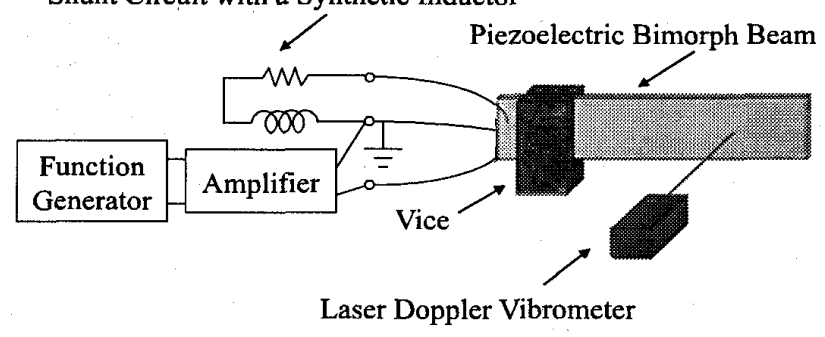

Fig. 7 Experimental setup for shunt damping

值を目標としてインダクタンスと抵抗の值をインピー ダンスアナライザを用いて調整した.

外乱用の圧電素子に振幅 $2 \mathrm{~V}$ のスイープ正弦波を $27.0 \mathrm{~Hz}$ から $47.0 \mathrm{~Hz}$ まで $16.0 \mathrm{sec}$ 加え, そのときの振 動速度をレーザドップラ振動計で計測する．計測位置 は先端から $10 \mathrm{~mm}$ の場所とした. サンプリング周波数 は $2048 \mathrm{~Hz}$ とし, $2^{15}$ 点のデータを取得する. 実験は それぞれの条件につき 3 回ずつ行った. 取得したデ一 タを用いて, 平均クロススペクトルと平均パワースペ クトルの比を計算し, 外乱用印加電圧から振動速度ま での周波数応答を推定した ${ }^{(10)}$. 得られた周波数応答 に $1 / j \omega$ をかけることで周波数領域の積分を行い，外 乱用印加電圧から振動変位までの周波数応答とした.

4.3.2 結果と議論 端子間を短絡して制振効果 がない場合と, シャント回路をつないだ場合との時間 応答をそれぞれ図 8 に示す. 制振しない場合では $5 \mathrm{sec}$ 付近で大きく共振しているのに対し, シャント回路を 接続した場合にはほとんど共振していないことがわ かる.

3 回の実験結果を平均して周波数応答を求めたもの を図 9 に示す. 横軸は周波数であり, 上から順にコヒー レンス, ゲイン，位相を表している．破線と点線はそ れぞれ端子間短絡と端子間開放の場合であり，実線は シャント回路を接続した場合である. およそ $28 \mathrm{~Hz}$ から $46 \mathrm{~Hz}$ までコヒーレンスがほぼ 1 であることから, 十 分に再現性の高い実験データであることがわかる．ま た, ゲイン線図から，実線が破線や点線と比べてずっ と小さくなっており, シャント回路によって大きな制 振効果が得られていることがわかる. なお, 点線の端 子間開放の場合には，制振効果はみられず，短絡の場 合に比べて共振周波数がわずかに高くなっていること がわかる．これは $2 \cdot 3$ 節で述べたように, 圧電・逆圧 電効果によって固有角振動数が $\omega_{1}$ から $\omega_{1}^{D}$ へと高く なるためである.
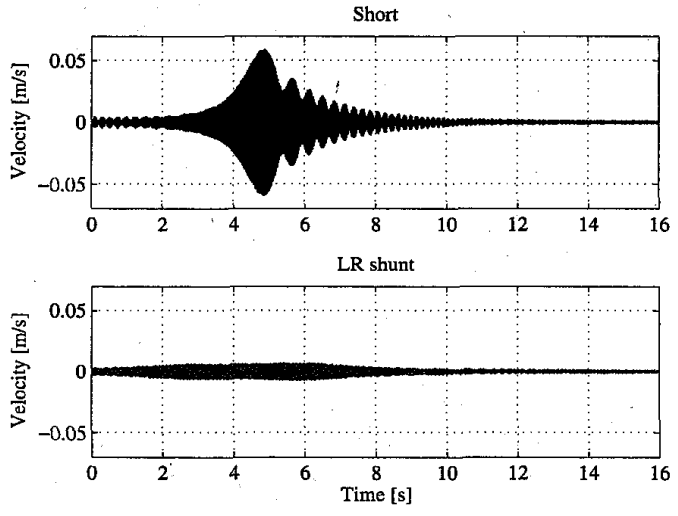

Fig. 8 Time response in the damping experiment
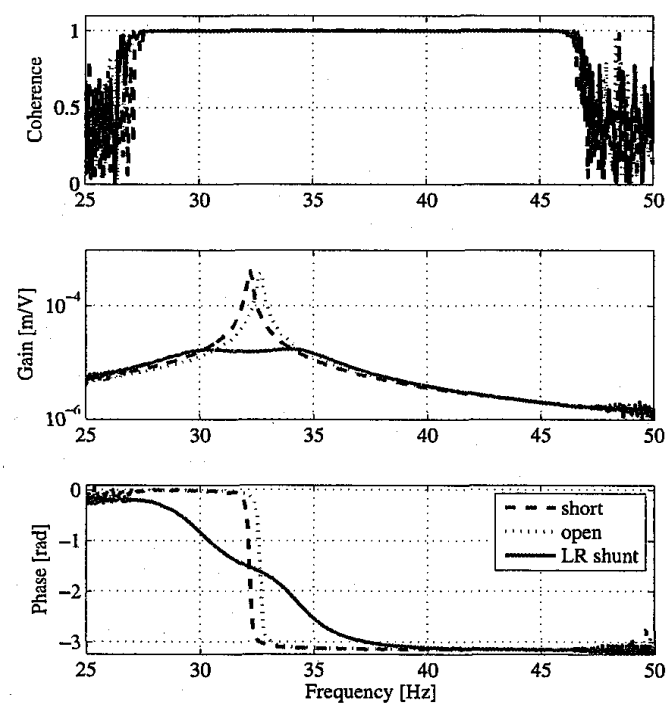

Fig. 9 Frequency response in the damping experiment

図 10 はゲイン線図だけを拡大したものであり, 端 子間短絡の場合に比べて, シャント回路を接続した場 合はおよそ $1 / 20$ 以下 $(-27.6 \mathrm{~dB})$ の低減になっている. また, 制振後のゲイン線図は, 最適設計された動吸振 器に見られる以下の特徴をもつ ${ }^{(4)}$.まず, 高さの等し い2つのなだらかなピークが確認できる. また, 端子 間短絡の場合とシャント回路を接続した場合とのゲイ ンの交点, すなわち定点の高さが等しくなっている. 図中定点は。で表してある. そして, 定点がほぼゲイ ンの極大值となっている.

以上の制振実験の結果は定点理論によって最適設計 された特徴がよく現れており, 推定ざれたパラメータ の妥当性が確認された. 


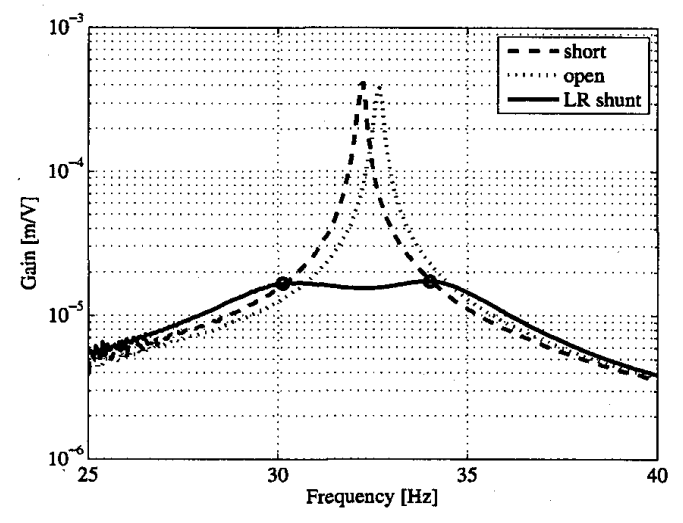

Fig. 10 Magnified view of the gain

\section{5. おわりに}

圧電材料を用いた構造物のシャント制振を目的とし て, 圧電構造物のインピーダンス計測だけに基づく パラメータ推定法を提案した. まず, 圧電素子の静電 容量が着目する周波数帯域によって異なることをイン ピーダンスのモデルから明らかにし, 振動モードごと に值が異なるモードキャパシタンスを定義した。 そし て, パラメータを推定する実験と, 推定したパラメー タを用いて設計したシャント回路による制振実験とを 行い,インピーダンスのモデルと推定手法の有効性を 確認した.

提案した推定手法はインピーダンス計測のみに基づ くため，センサが不要であるという特長をもつ．その ため, 推定手法は任意の大きさ・形状をもつ圧電構造 物に適用できる. また圧電素子の静電容量を精度よく 推定する方法としても有用であると期待される.

\section{文献}

(1) Adachi, K., Shunted Piezoelectrics for Structural Damping, Journal of the Society of Instrument and Control Engineers, Vol.42, No.9 (2003), pp.763-769.

(2) Moheimani, S.O.R., Fleming, A.J., Piezoelectric Transducers for Vibration Control and Damping, (2006), Springer.

(3) Takagi, K., Nagase, K., Oshima, K., Hayakawa, Y., Ichikawa, H., Optimization of Passive
Piezoelectric Shunt Damping Based on the Robust Performance Index, Transactions of the Japan Society of Mechanical Engineers, Series $C$, Vol.69, No.688 (2003), pp.3183-3190.

(4) Hagood, N.W., von Flotow, A., Damping of Structural Vibrations with Piezoelectric Materials and Passive Electrical Networks, Journal of Sound and Vibration, Vol.146, No.2 (1991), pp.243-268.

(5) Yamada, K., Matsuhisa, H., Utsuno, H., Park, J.G., Precise Measuring Method of Electromechanical Coupling Coefficient of Piezoelectric Element, Transactions of the Japan Society of Mechanical Engineers, Series C, Vol.71, No.710 (2005), pp.2896-2903.

(6) Porfiri, M., Maurini, C., Pouget, J., Identification of Electromechanical Modal Parameters of Linear Piezoelectric Structures, Smart Materials and Structures, Vol.16, (2007), pp.323-331.

(7) Kim, J., Ryu, Y., Choi, S., New Shunting Parameter Tuning Method for Piezoelectric Damping Based on Measured Electrical Impedance, Smart Materials and Structures, Vol.9, (2000), pp.867-877.

(8) Takagi, K., Nagase, K., Oshima, K., Hayakawa, Y., Ichikawa, H., An Experimental Identification Method for Piezoelectric Shunt Damping, Transactions of the Japan Society of Mechanical Engineers, Series C, Vol.70, No.690 (2004), pp.445-452.

(9) Hagood, N.W., Chung, W.H., von Flotow, A., Modelling of Piezoelectric Actuator Dynamics for Active Structural Control, Journal of Intelligent Material Systems and Structures, Vol.1, (1990), pp.327-354.

(10) Yasuda, K., Modal Analysis and Dynamic Design (in Japanese), (1993), Corona Publishing Ltd. 